\title{
Importance of climate change-physical forcing on the increase of cyanobacterial blooms in a small, stratified lake
}

\author{
Dolores PLANAS, ${ }^{1 *}$ Serge PAQUET ${ }^{2}$ \\ ${ }^{1}$ GRIL-UQAM, Départment de Sciences Biologiques, Université du Québec à Montréal, C.P. 8888 Suc. Centre Ville, Montréal, QC \\ H3C 3P8; ${ }^{2}$ GEOTOP-UQAM, Université du Québec à Montréal, C.P. 8888 Suc. Centre Ville, Montréal, QC, H3C 3P8, Canada \\ *Corresponding author: planas.dolores@uqam.ca
}

\begin{abstract}
The community structure of planktonic cyanobacteria was studied in a dimictic lake in which recurrent summer surface algal blooms have frequently occurred since the beginning of this millennium. In eutrophic-hypereutrophic lakes, epilimnetic cyanobacterial blooms are promoted by increased ambient temperatures and water column thermal stability, which favour the vertical migration of buoyancyregulating cyanobacteria. Here we propose that intensified external energy (wind) that alters thermocline stability could explain the occurence of heavy blooms in the surface of lakes with low external nutrient loading. Specifically, we hypothesized that: i) in small stratified lakes with low external nutrient sources, cyanobacterial growth primarily occurs near the lake bottom, where phosphorus is more abundant and light is available; ii) we additionally hypothesized that turbulence induced by strong winds increases the amplitude and energy of metalimnetic internal waves and entrains meta-and hypolimnetic water, rich in nutrients and cyanobacteria, into the epilimnion. The study was done in a small lake (45 Ha, maximum and mean depth $7.2 \mathrm{~m}$ and $4.3 \mathrm{~m}$, respectively) with mean epilimnetic dissolved phosphorus concentrations $\approx 4 \mu \mathrm{g} \mathrm{L}^{-1}$ and chlorophyll $\alpha \approx 8 \mu \mathrm{g} \mathrm{L}^{-1}$. Vertical temperature profiles during the open season were continuously registered using thermistors. Weekly vertical profiles of light transmission, phytoplankton distribution and water chemistry were also taken. On one occasion, these variables were measured throughout a continuous 24 h cycle. Results demonstrated that summer cyanobacterial blooms were dominated by Plankthotrix spp., which began their cycle in late spring at the bottom of the lake, and grew to form dense metalimnetic biomass peaks. Time series analysis of isotherms and the Lake number indicated that internal metalimnetic waves (seiches) were present through the summer. During the diel sampling cycle, we found that medium to strong westerly wind gust events ( $\sim 5$ to $\left.>12 \mathrm{~m} \mathrm{~s}^{-1}\right)$ induced large amplitude internal waves (mainly V2H1 mode) that vertically displaced the isotherms by more than $3.5 \mathrm{~m}$. During this event the top of the metalimnetic algal peak was entrained through the epilimnion, bringing metalimnetic Plankthotrix spp. to the lake surface, modified the deep metalimnion and hypolimnion concentrations of dissolved oxygen, and caused an upsurge in phosphorus. We conclude that algal and nutrient upwelling linked to intermittent deep mixing events, play an important role in supporting summer cyanobacterial blooms in lake Bromont.
\end{abstract}

Key words: Cyanobacteria blooms; deep chlorophyll maximum; oscillatoriales; turbulence; entrainment.

Received: September 2015. Accepted: October 2015.

\section{INTRODUCTION}

Climate change has major physical, chemical, and biological effects on aquatic ecosystems. Globally averaged air and ocean temperatures have both undisputably increased since 1850, and this trend has accelerated towards the end of the last century. The period from 1983 to 2012 was likely the warmest 30-year period of the last 800 years (IPCC high confidence; Pachauri and Meyer 2014).

In Northern Hemisphere, the greatest seasonal increase in air temperature has occurred in the winter, while summer heat waves occur more frequently, are both more intense and becoming longer in duration (Solomon et al., 2007). The consequences of such changes on the thermal regime in lakes have already been reported, including shorter periods of ice-cover, changes in water column density, and the earlier onset and longer duration of stratification (De Stasio et al., 1996; Peeters et al., 2002;
Stainsby et al., 2011). In addition, increasing precipitation is modifying watershed hydrology, intensifying runoff, and likely increasing nutrient loading (Parry et al., 2007). These changes have major implications for phytoplankton biomass and community structure. Phytoplankton communities are expected to undergo changes in species composition that generally favor cyanobacterial (CYAN) growth, particularly the harmful species (Pearl and Huismann, 2008; Pomati et al., 2012).

CYAN blooms have occurred for centuries, in both marine and freshwater systems (Fogg et al., 1973). Since the 1950s, CYAN blooms have increased worldwide in biomass, frequency and duration (Hallegraeff, 1993). This phenomenon has traditionally been attributed to anthropogenic perturbations, particularly phosphorus $(\mathrm{P})$ enrichment (Schindler, 1974). Lake eutrophication has decreased in the last 20-30 yrs, at least in western countries (Pomati et al., 2012), and eutrophied lakes have in 
many cases recovered, or are recovering after reduction or elimination of nutrient sources (Edmondson and Leman, 1981; Ruggiu et al., 1998; Jeppesen et al., 2005; Ibelings et al., 2007). In some cases, increases in temperature may offset the effects of oligotrophication by promoting the expansion of some forms of CYAN (Kosten et al., 2012). Further, in many cases the increase in CYAN is mainly due to increased growth of metalimnetic species. For instance, the relative abundance of Plankthotrix has increased in both alpine and Scandinavian lakes (Feuillade and Druart, 1994; Buergi and Stadelmann, 2000; Jacquet et al., 2005; Halstvedt et al., 2007).

Growing evidence suggests that variables related to climate, such as temperature and water-column stability, could explain additional or greater variation in CYAN abundance than nutrients (Soranno et al., 1996; Kosten et al., 2012). Kosten et al. (2012) found that the relative contribution of CYAN to total phytoplankton biomass increased with temperature across 143 lakes of varying trophic conditions along a latitudinal gradient from Northern Europe to Southern South America. Warming may lower the nutrient concentration thresholds at which CYAN blooms can be initiated and sustained (Weyhenmeyer, 2001; Nõges et al., 2003). Now it is clear that warming waters can have an additive effect on CYAN dominance in lakes, and augment the intensity and occurrence of blooms (Mooij et al., 2005; Jöhnk et al., 2008; Paerl and Huisman, 2009). The question is, what is the ultimate cause: climate, nutrients, or both? This question is difficult to answer because we have limited knowledge on the synergistic effects of nutrient loading and climate change in supporting CYAN.

Increased intensitity and frequency of wind and gusts linked to climate change may have large implications for lake stability dynamics. Climate change could modify the action of the wind on lake turbulence. Even small changes in convective-, and wind-driven mixing can have large implications for the internal transport and availability of nutrients in lake photic zones (Catalan and Fee, 1994). Accordingly, the ongoing warming of surface waters and changing water-column stability may be the primary drivers of CYAN abundance, particularly in stratified lakes (Jöhnk et al., 2008; Taranu et al., 2012). Increased frequency of episodic events (strong winds and storms) linked to climate change generates strong shear flow and turbulence through internal wave dynamics in stratified lakes (Imberberg, 1994). Though the study of physical processes in lakes began nearly a century ago (Wedderburn, 1913), the role of wind forcing on lake processes is rarely studied (Mortimer, 1974; Imberger, 1980; Imboden et al., 1983, among others). The importance of physical forcing to biological processes in lakes has gained increasing recognition in the last three decades (Reynolds, 1994; Oftrosvky et al., 1996; Evans et al., 2008; Marcé et al., 2007). But, these studies were done in largemedium size lakes or reservoirs. Recent evidence suggests that these effects have potentially large implications for CYAN dynamics in small lakes (Pannard et al., 2011).

Given the widespread warming trend in aquatic habitats worldwide, our research aim was to understand how changes in physical forcing related to warming may induce heavy surface CYAN blooms in small lakes. We were especially interested in the role that CYAN living in the deepest part of the water column may play in supporting summer surface blooms. Our hypothesis were:

H1. In stratified lakes with low external nutrient sources, CYAN growth occurs in the deep part of the lakes where $\mathrm{P}$ is more abundant, given sufficient light availability. This hypothesis is supported both by existing empirical data on deep phytoplankton maxima, and by models of maximum algal growth in relation to vertical light and nutrient availability (Fee, 1976; Klausmeier and Litchman, 2001).

H2. To explain why cyanobacteria growing below the thermocline cause surface blooms, we predicted that changing climate, including warming but also, increased wind-driven mixing, and heavy rainfall events, can enhance lake turbulence.

H2-1. Turbulence increases the amplitude and energy of metalimnetic internal waves (seiches) and reduces the stability of the thermocline.

$\underline{\mathrm{H} 2-2}$. Internal waves of high amplitude entrain metaand hypolimnetic water, rich in nutrients and organisms (CYAN), into the epilimnion, thereby causing surface CYAN blooms.

The hypotheses were tested in a small, stratified lake that experiences frequent and random summer CYAN blooms, despite low external P-loading.

\section{METHODS}

\section{Study site}

The study was done in Lake Bromont, located in the SE of Canada $\left(45^{\circ} 16^{\prime} \mathrm{N}, 72^{\circ} 40^{\prime} \mathrm{W}\right)$. The surface area of the lake is 45 ha and its drainage area 2410 ha; the volume $2 \times 10^{6} \mathrm{~m}^{3}$ and, mean and maximum depth are $4.5 \mathrm{~m}$ and $7.2 \mathrm{~m}$, respectively (Fig. 1).

The lake is set in a central plain surrounded by mountains and isolated hills extending eastward (Fig. 1). The main axis of the lake is in the East-West directon and the lake opens in the direction of dominant westerly winds, which are funnelled to the Eastern end of the lake. The recent study of Pannard et al. (2011) found persistent internal wave activities linked to the dominant winds. The spectral analysis of the isotherms has shown that the second (V2H1) mode waves dominated over the first mode (V1H1), which occurs only during larger wind events (Pannard et al., 2011). In the V2H1 mode the epilimnion and hypolimnion oscillate in the opposite direction con- 
secutively, thereby squeezing and broadening the metalimnion vertically. The V2H1 mode, in resonance with diurnal winds, is the primary cause of the large amplitude of the second mode (Münnich et al., 1992)

The lake has four permanent inflowing streams and one outflow. Until 1990, agriculture was the main activity in the largest (60\%) and second largest (16\%) sub-watersheds, respectively located to the South and North of the lake. Loading of $\mathrm{P}$ from the south stream represented 80 to $90 \%$ of riverine total phosphorus (TP) inputs. Presently, farmland in the watershed is mainly composed of pasture (Pannard et al., 2011). Since the early 1990s, efforts to protect the lake have increased, culminating in the recent formation of the Watershed Conservation Action Lac Bromont association.

\section{Meteorological data}

Wind speed and direction, plus precipitation data, were collected from a weather station installed on a raft on the lake (Fig. 1). Here, reported wind velocities are averages of observations made at $15 \mathrm{~min}$. intervals, and wind gust speeds are the averaged maximum speed across intervals. Pannard et al. (2011), found a good relation between wind velocity and the surface current velocities measured in the lake.

\section{Physical, chemical and biological data}

Sampling was done in the ice-free season (April-May to October) of 2010, at the deepest part of the lake (Fig 1). In situ water temperature was continuously registered with 3 strings of moored Hobo Pro temperature loggers, at $50 \mathrm{~cm}$ intervals between 1 and $3 \mathrm{~m}$, then every $25 \mathrm{~cm}$ from 3 to $6.75 \mathrm{~m}$. The calibrated thermistors (accuracy $\pm 0.2^{\circ} \mathrm{C}$ between $0^{\circ} \mathrm{C}$ and $50^{\circ} \mathrm{C}$ ) recorded measurements every $10 \mathrm{~min}$. Light transmission, chemical and biological variables were sampled weekly at the deepest part of the lake. Photosynthetic Active Radiation (PAR) profiles were measured in situ at $25 \mathrm{~cm}$ intervals using a submersible spherical sensor (Li-193) and the incident light reaching the lake surface was recorded with an air sensor (Li-190) (LICOR-Environment, Lincoln, NE, USA). To characterize the oxycline we measured dissolved oxygen (DO) at $0.5 \mathrm{~m}$ depth intervals with a YSI 6920 sonde (YSI Environmental, San Diego, CA, USA). The vertical structure of phytoplankton was measured at every centimetre in situ with a FluoroProbe (Biological Biophysical Engineering BBE Moldaenke GmbH, Kiel-Kronshagen, Germany). The FluoroProbe distinguished four taxonomic groups (Beutler et al., 2002). The accuracy of CYAN biomass estimated by the fluoroprobe was validated by identifying, counting and measuring the species sampled at discrete

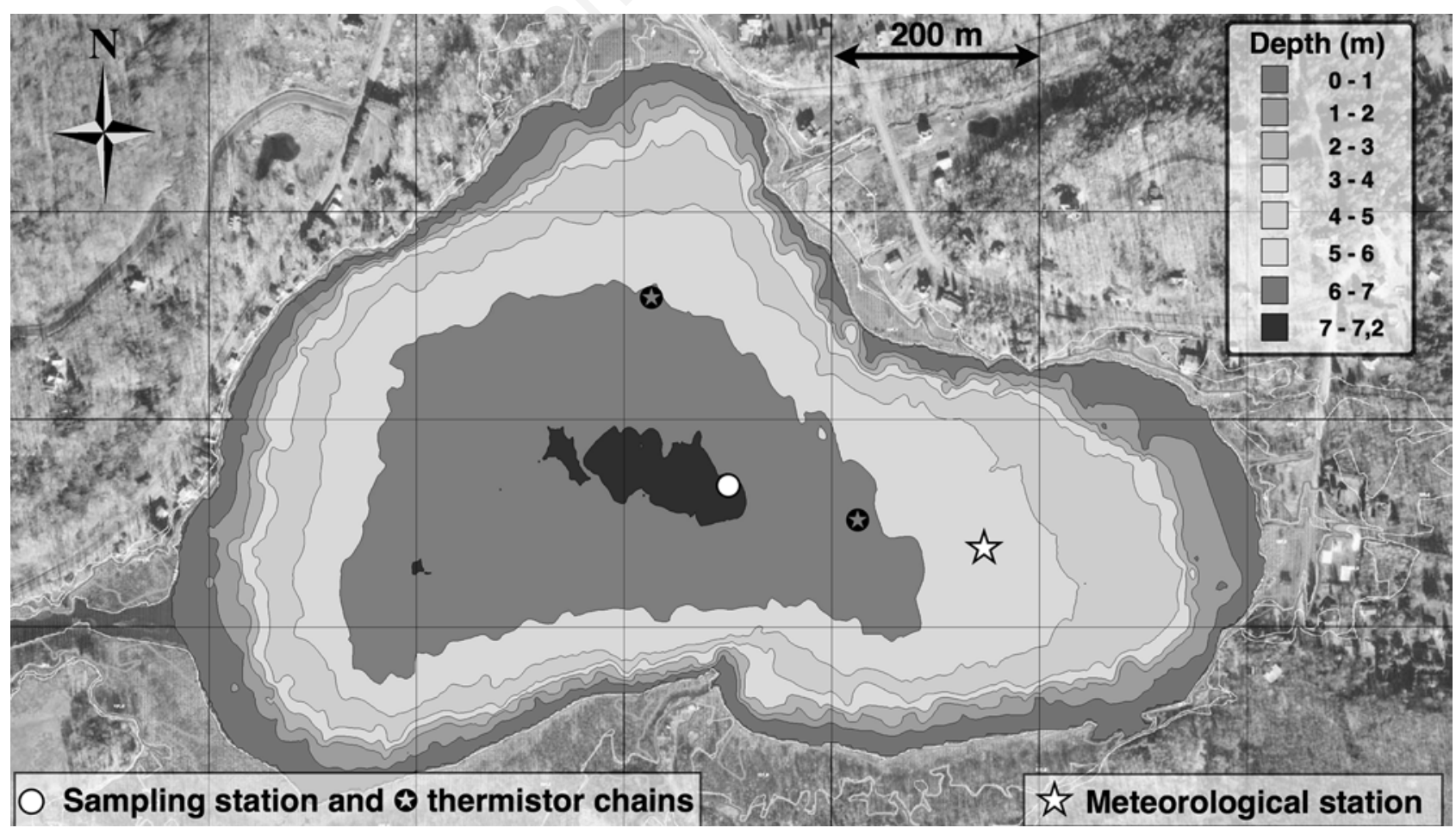

Fig. 1. Bathymetric map of lake Bromont. The white dot marks the sampling station, the star shows the placement of the meteoreological station, and the circle with the star shows the location of the thermistor chains. 
depths (see below), with an inverted microscope, using the Utermöhl technique. The spatio-temporal distribution of CYAN was estimated in each $0.5 \mathrm{~m}$ strata of the epi-, meta-, and hypolimnion from fluoroprobe-derived concentrations of chlorophyll a (Chla).

Discrete water samples were collected with a van Dorn bottle $(37 \mathrm{~cm}$ length) in the middle of each thermal strata in the epilimnion and metalimnion, and at $0.5 \mathrm{~m}$ above the sediment layer in the hypolimnion. Water for chemical and biological analyses was collected in clear acid washed bottles, and dark detergent washed bottles, respectively. Immediately after sampling, samples were collected for total dissolved P (DP) by filtration across acid washed polycarbonate nucleopore filters $(0.45 \mu \mathrm{m})$ and Chla by filtering suspended materials onto GF/F filters. Phytoplankton samples were preserved with lugol solution. All samples were kept cool when travelling from the lake to the Laboratory. Nutrient samples were analyzed within $24 \mathrm{~h}$ of collection, and Chla was frozen at minus $80^{\circ} \mathrm{C}$ until analysis.

Dissolved (DP) and total P (TP) were digested in an autoclave at $150 \mathrm{~atm}$ with persulfate solution (Menzel and Corwin, 1965) and determined using the molybdenum blue colorimetric method (Murphy and Riley, 1962, modified by Stainton et al., 1974). Chla was extracted with hot ethanol (Nusch, 1980) and measured, before and after acidification, by spectrophotometry (Sartory and Großßelaar, 1984). The spatial-temporal distribution of CYAN biomass for individual strata was estimated from the concentration of Chla measured by the fluoroprobe profiles. Total FluoroProbe's Chla estimates and spectrophotometric concentrations of Chla were highly correlated $\left(r^{2}=0.94\right.$; $\mathrm{n}=19$; Pannard et al., 2015).

We used sediment peepers (Hesslein, 1976) to measure P-fluxes from the sediments following the modified method of Carignan (1984). Peepers were deployed, for 2-4 weeks, at the central station of the lake by divers. We measured DP with the same methods as in the water column, except that samples were not filtered and digested, since samples collected by the peepers were already in inorganic form. Fluxes from the sediments were estimated following Carignan and Lean (1991).

\section{Wind mixing calculations}

Lake Number, $\mathrm{L}_{\mathrm{N}}$, was calculated on a daily basis from the continuous in situ temperature record (see below) following methods of Imberger and Patterson (1989). $\mathrm{L}_{\mathrm{N}}<1$ indicates a fully mixed water column; a value very close to 1 indicates that there is upwelling of hypolimnetic waters; and a $\mathrm{L}_{\mathrm{N}}$ between 1 to 12 is characteristic of internal waves $L_{N}>12$, indicates calm and stable stratification (Robertson and Imberger, 1994). See Pannard et al. (2001) for more details.

The amount of $\mathrm{P}$ entrained in the epilimnion from the metalimnion when the thermocline deepened $1 \mathrm{~m} \mathrm{~d}^{-1}$ (Soranno et al., 1997) was calculated by the volume of water transported (estimated from bathymetric data), multiplied by the average P-concentration at the thermocline depth (Kamarainen et al., 2009).

\section{RESULTS AND DISCUSSION}

\section{Local climate change}

Mean air temperature near lake Bromont for this millennium was $\sim 1^{\circ} \mathrm{C}$ higher that in the previous $50 \mathrm{yrs}$ (mean temperature from 1948 to $1999=5.95^{\circ} \mathrm{C}$, and from 2000 to $\left.2014=6.98^{\circ} \mathrm{C}\right)$. In the last 15 years, minimum temperatures rose more $\left(+5^{\circ} \mathrm{C}\right)$ that maximum $\left(+{ }^{\circ} \mathrm{C}\right)$ values. The trend over the past 15 years is consistent with the global trend, for which the last decade was the hottest of the entire 160-year temperature record (Pachauri and Meyer, 2014). Additionally, the frequencies of storms associated to gust events have undergone noticeable changes (data not shown).

\section{Thermal structure}

Summertime mean ( \pm 1 SD) epi-, meta-, and hypolimnetic temperatures were $23 \pm 2.5^{\circ} \mathrm{C}, 17 \pm 3.2^{\circ} \mathrm{C}$ and $12 \pm 0.91^{\circ} \mathrm{C}$, respectively (Tab. 1). From mid July to the end of August, a heat wave raised epilimnetic water temperatures to up to $29.33^{\circ} \mathrm{C}$ from July $7^{\text {th }}$ to $16^{\text {th }}$ (Fig. 2a). In the metalimnion, temperature oscillated as a function of the amplitude of internal waves. Stratification in 2010 lasted 175 days (Tab. 1). Within the 5 years study, the length of the stratification augmented half a month between 2007-2008 and 2009-2010.

Lake Bromont became thermally stratified almost immediately following ice melt (Fig. 2a). In 2010, ice melt occurred the $1^{\text {st }}$ week of April, three weeks earlier than in previous study years (in preparation), but stratification remained weak until the end of April. The thermal structure of the lake was characterized by a relatively shallow mixed layer (2-3 $\mathrm{m}$ ) a thicker metalimnion (3-4 $\mathrm{m}$ ) and a thin hypolimnion (1-1.5 m) (Fig. 2a). Thicker metalimnia are common in small lakes (LaZerte, 1998).

Small diurnal changes in surface water temperature were registered in the lake. Internal metalimnetic waves (seiches) were present almost through the whole summer, as indicated by $\mathrm{L}_{\mathrm{N}}$ values between 1 and 12 from the end of May to mid-September (see below, Fig. 3a). Temperature shifts within the metalimnon were more frequent than in the epilimnion, a phenomenon that has been observed in the lake in 2007 (Pannard et al., 2011). Dominant westerly winds had diurnal periodicity, and surface current velocity was proportional with the wind speed (Pannard et al., 2011). Following wind events $>5 \mathrm{~m} / \mathrm{sec}$, large amplitude internal waves were observed in the metalimnion after winds subsided. Gust wind events $>15 \mathrm{~m} \mathrm{sec}$ in early 
May and late August strongly modified the vertical thermal structure of the lake, and caused an upwelling of hypolimnetic waters (Figs. 2a, 3a).

\section{Oxygen and phosphorus structure}

Phosporus concentrations [P] (Tab. 1) and oxygen concentrations $\left[\mathrm{O}_{2}\right]$ (Fig. 2b) in Lakes Bromont were strongly stratified, though chemical stratification was temporally perturbed by winds that induced high amplitude internal waves. Dissolved oxygen concentrations were closely related to vertical thermal stability. Following ice melt, the whole water column was super-saturated with $\mathrm{O}_{2}$ but $\mathrm{O}_{2}$ diminished in the lower metalimnion to $<25 \%$ saturation following the onset of stratification. A hypo-anoxic period $\left(\mathrm{O}_{2}\right.$ $<5 \%$ saturation) began at the lake bottom in spring and progressively expanded upward in the metalimnion, reaching $3 \mathrm{~m}$ above the lake bottom in August (Fig. 2b). The length of the anoxic period was 126 days (Tab. 1).

During anoxic periods, sediments release $\mathrm{P}$ to the water column and augment internal P loads (Nürnberg, 1984). Internal loading (4273 kg during summer; Tab. 1) was extremely high, and represented the main input of $\mathrm{P}$ in lake Bromont since external P-loads are relatively low (222 kg in 2010; Tab. 1). Such a high quantity of internal $\mathrm{P}$ loading is expected, due to the intensity and long duration of anoxia.

It is well established that sedimentary P loading plays an important role in overall shallow lake nutrient dynamics following reductions in external loading (Søndergaard et al., 2003; Jacquet et al., 2005), as was the case for lake Bromont. The spatio-temporal distribution of $\mathrm{P}$ (Table 1) showed a decreasing gradient from the epi- to hypolimnion. Mean [DP] ranged from $4 \pm 2 \mu \mathrm{g} \mathrm{L}^{-1}$ in the epilimnion, to $7 \pm 3 \mu \mathrm{g} \mathrm{L}^{-1}$ in the meta-, and $11 \pm 14 \mu \mathrm{g} \mathrm{L}^{-1}$ in the hypolimnion, while mean [TP] ranged from $18 \pm 8 \mu \mathrm{g}$ $\mathrm{L}^{-1}$ in the epilimnion, to $51 \pm 31 \mu \mathrm{g} \mathrm{L}^{-1}$ in the meta-, and $102 \pm 95 \mu \mathrm{g} \mathrm{L}^{-1}$ in the hypolimnion (Tab. 1). Sedimentary P release likely responded to temperature increases, in ad- dition to anoxia, since a $1-2^{\circ} \mathrm{C}$ increase in hypolimnetic temperature could intensify the release of $\mathrm{P}$ from $9 \%$ to 57\% (George et al., 2004).

\section{Cyanobacterial structure}

The algal biomass was generally low in the epilimnion of lake Bromont. Mean epilimnetic [Chla] was $8 \pm 4.3 \mu \mathrm{g}$ $\mathrm{L}^{-1}$, but increasing with depth, as meta- and hypolimnetic means were $13 \pm 14.0 \mu \mathrm{g} \mathrm{L}^{-1}$, and $24 \pm 24.8 \mu \mathrm{g} \mathrm{L}^{-1}$, respectively (Tab. 1). Concentrations ranged greatly, from 2-18 $\mu \mathrm{g} \mathrm{L}{ }^{-1}, 2-82 \mu \mathrm{g} \mathrm{L}^{-1}$, and 4-150 $\mu \mathrm{g} \mathrm{L}^{-1}$, in the epi-, metaand hypolimnion respectively, with the greatest range in the meta- and hypolimnion.

From late spring onward, phytoplankton community composition was dominated by CYAN, which represented more than $80 \%$ of the total community during the whole summer. The dominant specie was Planthothrix spp. (formerly Oscillatoria). Two Planthothrix species were present in the meta- and hypolimnion: P. agardhii (Gomont) Anagnostides \& Komarek, and P. rubescens Gomont. Since the counting was on fixed lugol's samples, we could not ascertain the species, but the color of the Planthotrix blooms was always very green. It is known that these two Plankthotrix species had similar depth distribution in some lakes (Halstvedt et al., 2007). Furthermore, it has recently been reported that the horizontal transfer of genes, involved in the synthesis of the photosynthetic pigments, occurs between red and green strains of this genus, including P. agardhii and P. rubescens strains (ToomingKlunderud et al., 2013).

Other relatively abundant CYAN were, Dolichospermum spiroides (Klebahn) L. Wacklin, L. Hoffman \& J. Komárek, Dolichospermum flosaquae P.Wacklin, L.Hoffmann \& J.Komárek, Dolichospermum solitaria (Klebahn), Aphanizomenon gracile (Lemmerm.), Aphanizomenon flexuosum (Kom. Et Kovàcik), Aphanizomenon flosaquae Ralfs ex Bornet \& Flahault. Relative abundances of each of these species vary spatially or/and temporally through

Tab. 1. Mean and standard deviation of environmental conditions during the open season at Lake Bromont. Air temperature (T) was registered on the lake weather platform, while water temperature, dissolved phosphorus (DP), total phosphorus (TP), and chlorophyll (Chl) were measured independently in each thermal strata. Other data include the duration of lake stratification, duration of bottom anoxia, and masses of external and internal phosphorus loading.

\begin{tabular}{|c|c|c|c|c|}
\hline & Open season & Epilimnion & Metalimnion & Hypolimnion \\
\hline $\begin{array}{l}\mathrm{T}_{\text {air }}\left({ }^{\circ} \mathrm{C}\right) \\
\mathrm{T}_{\text {water }}\left({ }^{\circ} \mathrm{C}\right) \\
\mathrm{DP}\left(\mu \mathrm{g} \mathrm{L}^{-1}\right) \\
\mathrm{TP}\left(\mu \mathrm{g} \mathrm{L}^{-1}\right) \\
\mathrm{Chl}\left(\mu \mathrm{g} \mathrm{L}^{-1}\right)\end{array}$ & $20 \pm 4.2$ & $\begin{array}{l}23 \pm 2.5 \\
4 \pm 2 \\
18 \pm 8 \\
8 \pm 4.3\end{array}$ & $\begin{array}{c}17 \pm 3.2 \\
7 \pm 3 \\
51 \pm 31 \\
13 \pm 14\end{array}$ & $\begin{array}{c}12 \pm 0.9 \\
11 \pm 14 \\
102 \pm 95 \\
24 \pm 25\end{array}$ \\
\hline $\begin{array}{l}\text { Stratification (days) } \\
\text { Anoxia (days) } \\
\text { TP Loading - external }(\mathrm{kg}) \\
\text { TP Loading - internal }(\mathrm{kg})\end{array}$ & $\begin{array}{c}127 \\
126 \\
222 \\
4273\end{array}$ & & & \\
\hline
\end{tabular}


the open season, since they occupy different niches among the epi-, meta-, and hypolimnion (Jourdain, 2010; Cabal Gomez, 2014). D. flosaquae was dominant in the littoral zone, and caused spring blooms in the lake (Figure $3 \mathrm{~b}$, end May). A. gracile and A. flexuosum were present in the epiand upper metalimnion; their distribution was modulated by internal waves that affected their light exposure and nu- trient availability at the epi-metalimnion boundary (Litchman, 1998; MacIntyre et al., 1999; Jourdain, 2010; Pannard, et al., 2011; Cabal Gomez, 2014).

Planthothrix spp. started to grow at the bottom of the lake around the summer solstice, when the euphotic zone was more that $6 \mathrm{~m}$ (see below). It persisted and grew in the meta- and hypolimnion for the whole summer, forming a

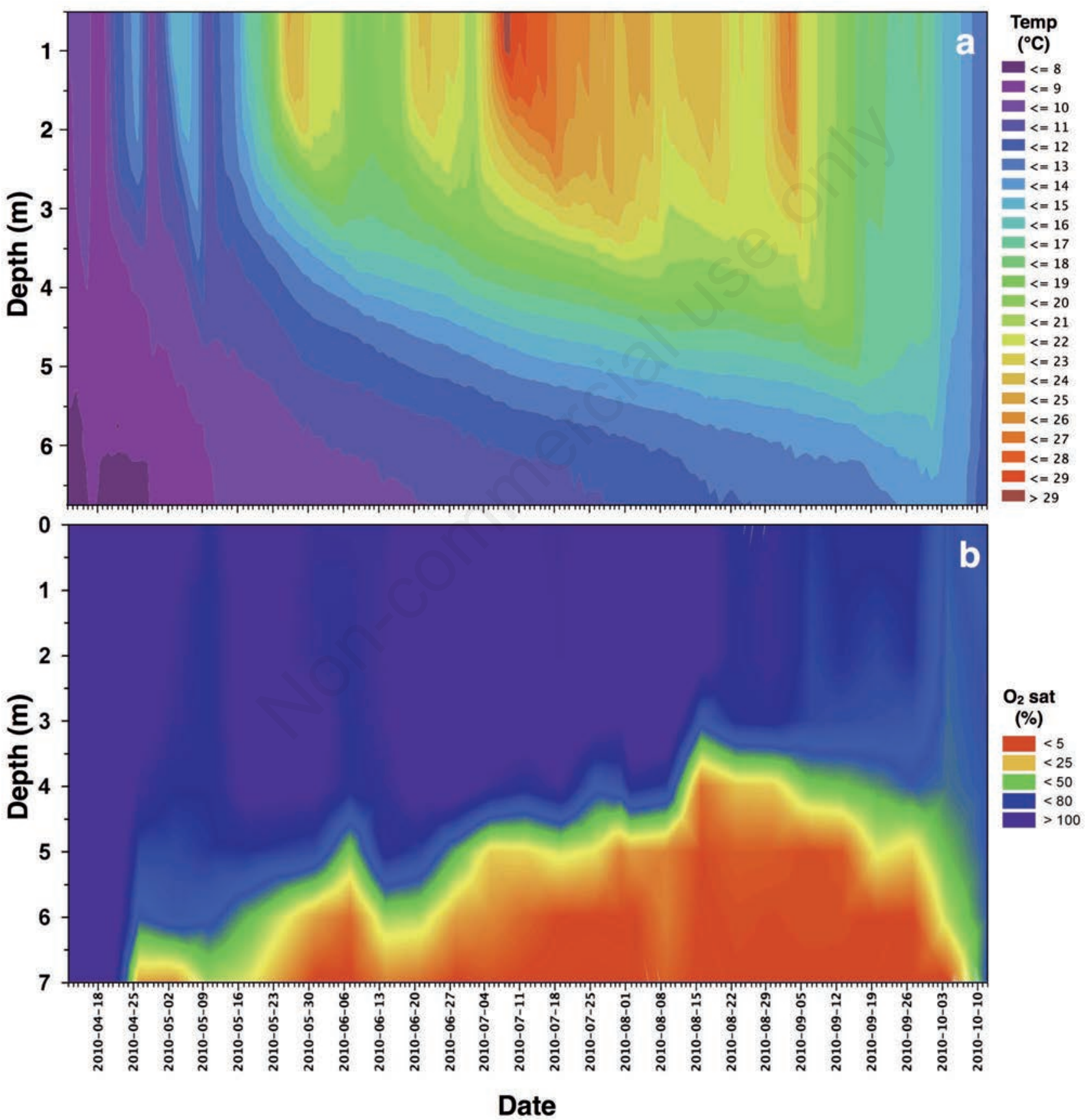

Fig. 2. Temporal changes in vertical (a) temperature based on continuous in situ measurements, and (b) weekly measurements of dissolved oxygen saturation. 
very thick Deep Chlorophyll Maximum (DCM) (Fig. 4c). Maximum biomass occurred in the lake in spring and early summer, at 6-7 $\mathrm{m}$ depth, and persisted until the middle of July with concentrations reaching $200 \mu \mathrm{g} \mathrm{L}^{-1}$ (6 m, July $\left.5^{\text {th }}\right)$. The CYAN peak expanded vertically up to $4 \mathrm{~m}$ until the beginning of August, then shifted upward to depths of 3-4 m, following increased surface wind speed (Fig. 4 a,b) that induced mixing of epi- and metalimnetic waters, and decreased epilimnetic temperatures (Figs. 2a, 3a). At the beginning of September, strong wind gusts deepened the epilimnion to below $5 \mathrm{~m}$, causing the DCM to disappear and CYAN to be uniformly distributed throughout the epilimnion (Figs. 2a, 4 a,c). The total biomass measured in the meta- and hypolimnion DCM was around $1900 \mathrm{~kg}$ in 2010 and was highly correlated to hypolimnetic TP $(\mathrm{r}=0.92$; $\mathrm{P}=0.0262$.

The diminution of Planthothrix spp. during fall entrainment could be explained by growth-limiting dilution of DPconcentrations (Walsby and Schanz, 2002), or by competition with A. flosaquae, which became very abun-

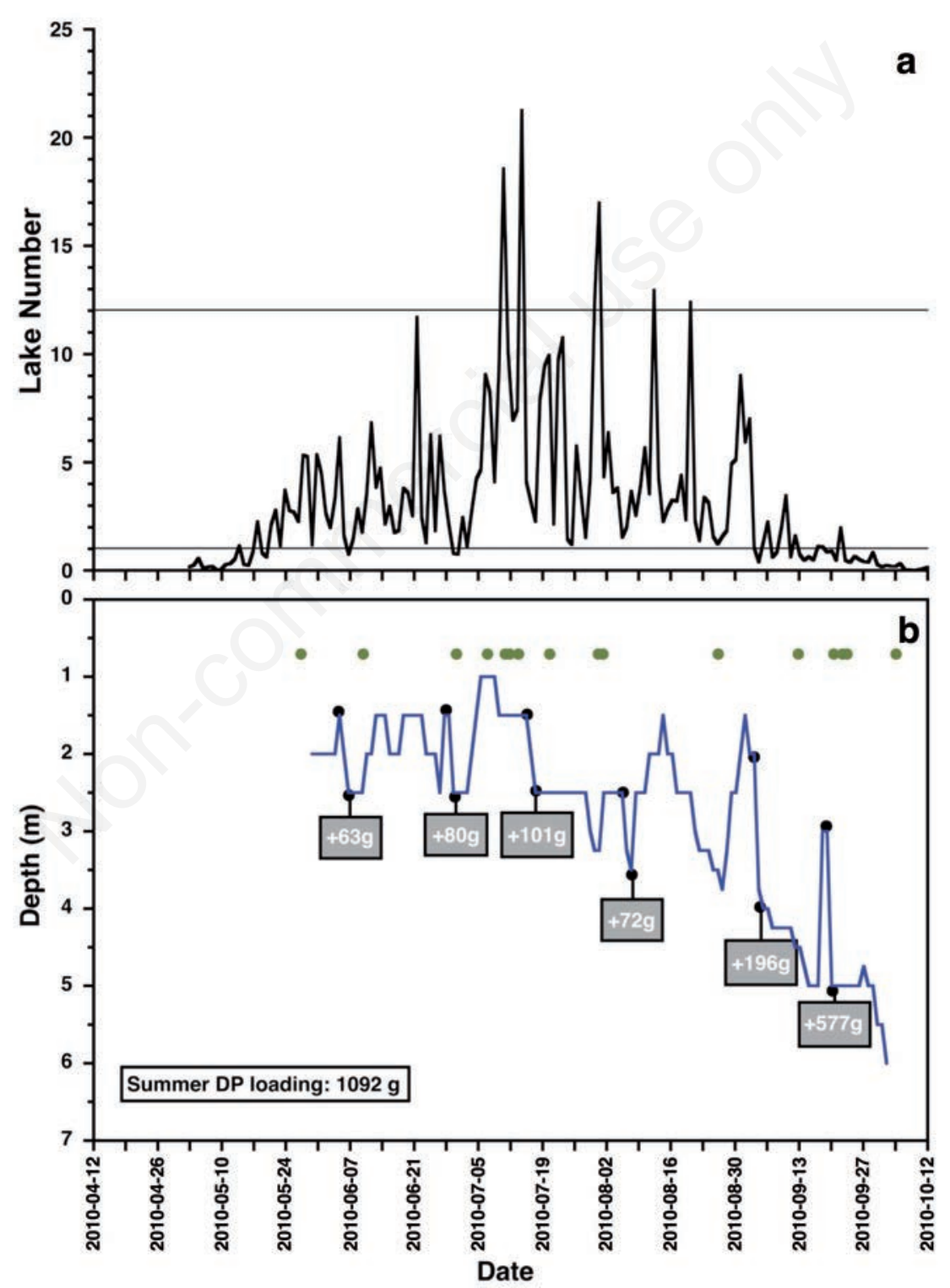

Fig. 3. a) $\mathrm{L}_{\mathrm{N}}$ calculated from in situ thermistors. b) Epilimnetic disolved phosphorus entrainment. The continuous line shows the thermocline depth, grey boxes show the amount of phosphorus entrained following individual thermocline deepenings, and the white box is the sum of each event during the study period. The green dots in the top show the days with surface blooms; black dots denote daily thermocline variation when changes exceeded $1 \mathrm{~m}$ in depth. 

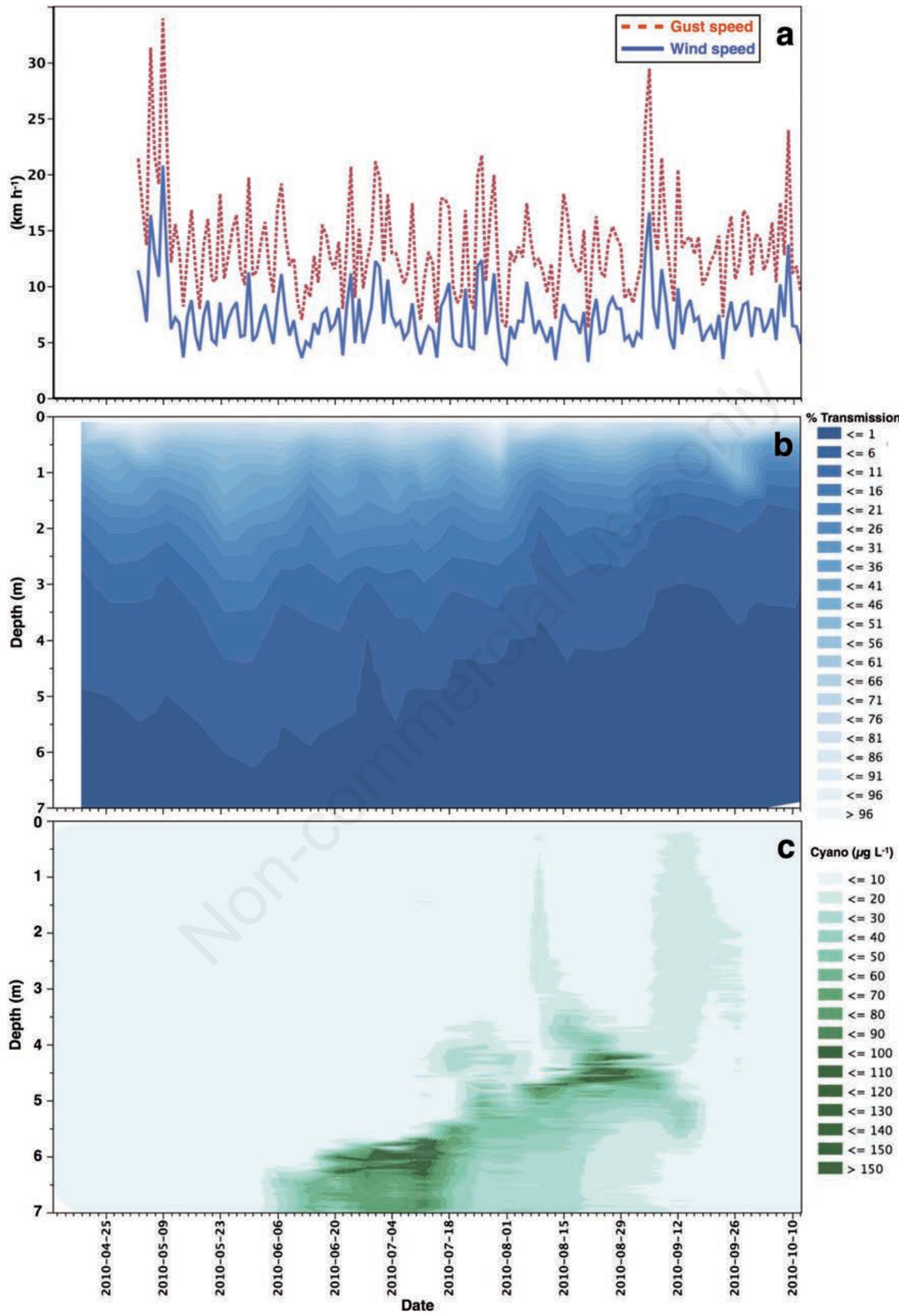

Fig. 4. a) Wind and gust speed measured at the lake metereological station. b) Spatio-temporal distribution of the \% of photosynthetic active radiation transmited in the lake. c) Spatio-temporal distribution of the cyanobacterial biomass measured in situ. 
dant in the fall overturn. Growth of $A$. flosaquae began in the metalimnion in August, persisting in the water column until the onset of ice-cover, with frequent $A$. flosaquae surface blooms throughout this period (data non presented). The late spring and summer metalimnetic growth of both, $P$. agardhii and $P$. rubescens, is well documented across different continents, mainly in deep subalpine European lakes and in small lakes and reservoirs (Klemer, 1976; Konopka, 1982; Ramón and Moyá, 1984; Ruggiu and Mosello, 1984; Micheletti et al., 1998; Salmaso, 2000; Jacquet et al., 2005; Kangro et al., 2005; Halstvedt et al., 2007). In lake Bromont, the growth and persistence of Planthothrix spp. in the meta- and hypolimnion may be linked to ideal physical and chemical conditions that favour the growth of these species; namely low temperatures, sufficient light availability, and high nutrient supply (Van Liere and Mur, 1979; Feuillade, 1994). In lake Bromont, mean summer temperatures were around $17^{\circ} \mathrm{C}$ in the metalimnion and around $12^{\circ} \mathrm{C}$ in the hypolimnion (Tab. 1), while irradiance was variable, changing in relation to internal waves and selfshading (Fig. 4b). Elevated bottom-water P-concentrations were sustained by sedimentary loading of DP, which supported $P$. agardhii and A. flosaquae dominance in the DCM. Low summertime epilimnetic DP-concentrations limited CYAN growth in surface waters during stratification (Tab. 1).

\section{Light climate}

Light transmission was influenced by internal wave dynamics through self-shading. In the spring, between 2 to 8 $\mu \mathrm{mol}$ photons $\mathrm{m}^{-2} \mathrm{~s}^{-1}$, reach $6.5-7 \mathrm{~m}$, and these light conditions supported the onset and growth of CYAN between 7 and $6 \mathrm{~m}$ (see below, Fig. $4 \mathrm{~b}, \mathrm{c}$ ). At the beginning of July, mixing and upwelling of hypo-metalimnetic waters (Figs. $3 b, 4 b, c)$ caused increased CYAN growth and its vertical expansion above the $6 \mathrm{~m}$ depth, which in turn caused a reduction in light penetration depth that lasted the entire month (Figs. 2a, 3 a,b, 4 a,b). Two more important changes in light transmission linked to CYAN growth occurred between the end of July to the beginning of September, when periods of strong metalimnion mixing alternated with stable stratification and the DCM peak was shallower (Figs. 3a, 4 b,c). Following strong winds at the beginning of September, the DCM disappeared for the rest of the month when the mixed layer depth deepened to below $4.5 \mathrm{~m}$, and DCM algae were distributed throuhgt the water column in parallel to an increase in light penetration and a huge upsurge of DP (Fig. 4 a,b). In combination, these effects supported surface algal growth that lowered light transmission and caused the disappearance of CYAN in the deep waters (Fig. 4 b,c).

\section{Bloom occurrence and physical forcing}

In lake Bromont, summer surface blooms have occured almost every year since 2006, at variable frequency and intensity (e.g., few and small in biomass in 2007, but frequent, intense and long lasting in 2010 to 2011 (Cabal Gomes, 2014). Summer blooms in lake Bromont were formed by Planthotrix spp., the dominants species present in the DCM metalimnnetic peak. These blooms were associated with the upsurge of metalimnetic waters (Fig. $3 \mathrm{~b}$ ), which were responsible for the delivery of $1 \mathrm{~kg}$ of $\mathrm{DP}$, and $8 \mathrm{~kg}$ of TP and $7 \mathrm{~kg}$ of particulate phosphorus (PP) to the epilimnetic layer. Here, PP consisted mainly of algal-P contained in bloom-forming Planthotrix.

We used diurnal sampling over a 36-h period between the $9^{\text {th }}$ and $10^{\text {th }}$ of July, to elucidate the bloom dynamics of CYAN during an intense bloom period. Diel sampling coincided with the onset of a heat wave that caused a surface to bottom lake temperature gradient of almost $20^{\circ} \mathrm{C}$, during which time [Chla] at the DCM peak reached $>150$ $\mu \mathrm{g} \mathrm{L} \mathrm{L}^{-1}$. The cycle started at sunrise on July $9^{\text {th }}$, when an intense surface Plankthotrix spp. bloom was present. The [Chla] at the DCM peak at $6.0 \mathrm{~m}$ was $75 \mu \mathrm{g} \mathrm{L} \mathrm{L}^{-1}$ and a secondary smaller peak $\left(23 \mu \mathrm{g} \mathrm{L}^{-1}\right)$ was present at $4.5 \mathrm{~m}$ (Fig. 6a). At sunrise, the gust speed was very low, $<4 \mathrm{~m} \mathrm{~s}^{-1}$, but increased to around $6 \mathrm{~m} \mathrm{~s}^{-1}$ from 9 a.m. to 5 p.m. Consequently, internal wave oscillations increased, but the disturbance of the DCM was probably compensated by algal primary production. The algal biomass at the DCM peak increased from 5 a.m. to 8 p.m. (Fig. 6a).

In the evening of the $9^{\text {th }}$ of July, two storms were registered, the first at 6 p.m., which was accompanied by strong SW winds, with gust velocities up to $13 \mathrm{~m} \mathrm{~s}^{-1}$ (Fig. $5 a)$, not strong winds were associated with the second. Three hours after the occurrence of these strong winds, the amplitude of metalimnetic internal wave oscillations increased (Figs. $5 \mathrm{a}, \mathrm{c}$ ), with the 2 and $5.75 \mathrm{~m}$ isotherms in phase, and a $2^{\circ} \mathrm{C}$ isotherm deflection occurring at the epi-metalimnetic boundary. Within this period, the $4 \mathrm{~m}$ isotherm was out of phase (the second vertical wave mode, $\mathrm{V} 2 \mathrm{H} 1$, dominated during the cycle), causing larger amplitude oscillations that in turn generated temperature fluctuations of up to $3.25^{\circ} \mathrm{C}$ (Fig. 5c). The enhanced metalimnetic turbulence disrupted the CYAN-DCM peak. It swept the algae at the surface and subsurface of the peak upward into the epilimnion and biomass decreased at the DCM at the peak, and a huge bloom was observed again in the sunrise samplings of the $10^{\text {th }}$ July (Figs. 5c, 6a).

It is known that in lakes with a thick metalimnion, wind events can alter patterns of internal waves, causing brief occurrence of the V1H1 mode, followed by the dominance of the V2H1 mode (Münnich et al., 1992; Pannard et al., 2011). In Lake Bromont, Pannard et al. (2011) observed changes in thermal structure when surface current velocity exceeded $10 \mathrm{~cm} \mathrm{~s}^{-1}$, since surface currents were strongly dependent on the speed of westerly winds above the lake surface. Consistent with our findings, Pannard et al., (2011) also observed large temperature fluctuations 

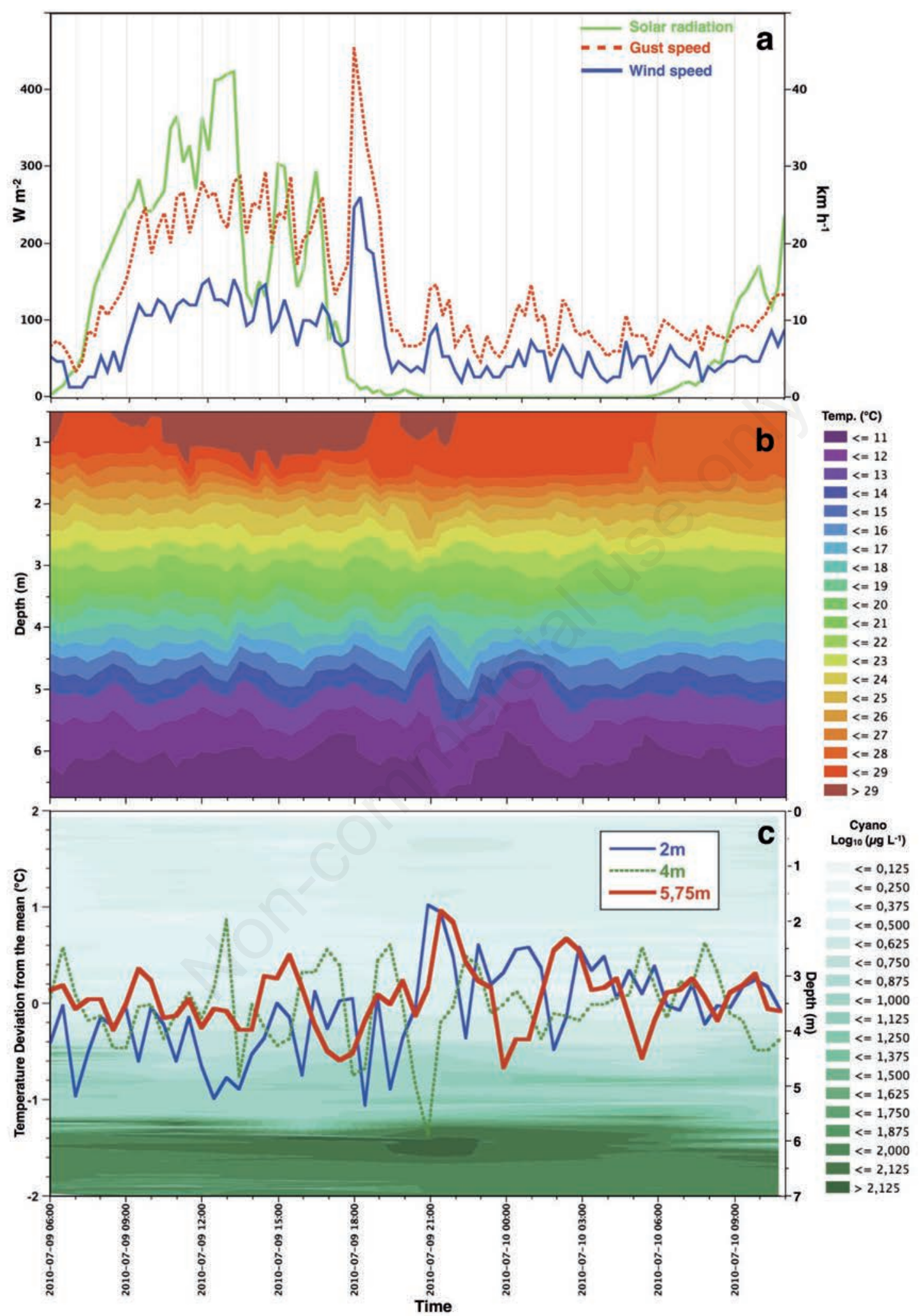

Fig. 5. Hourly physical and algal biomass data during the $24 \mathrm{~h}$ cycle ( 9 July at sunrise to 10 July at 10 a.m.). a) Incident photosynthetic active radiation ( $\mathrm{W} \mathrm{m}-2)$ measured at the lake metereological station, wind speed $\left(\mathrm{km} \mathrm{h}^{-1}\right)$ and the gust speed $\left.\left(\mathrm{km} \mathrm{h} \mathrm{h}^{-1}\right) . \mathrm{b}\right)$ Hourly vertical profiles of temperature measured by in situ thermistor chains. c) Temperature deviations from the daily mean at three depths; $5.75 \mathrm{~m}$ (deeper metalimnion), $4 \mathrm{~m}$ (mid-metalimnion), and $2 \mathrm{~m}$ (meta-epilimnion boundary). In the background of the figure, changes in cyanobacterial biomass over $5 \mathrm{~h}$ time intervals are shown. 
that coincided with maximum amplitudes at $4.5 \mathrm{~m}$ depth in lake Bromont. It has been reported that winds in excess of $10 \mathrm{~m} \mathrm{~s}^{-1}$ cause the rates of dissipation of turbulent kinetic energy to be high (MacIntyre and Jellison, 2001). Kinetic energy introduced to the lake by wind is transferred to metalimnetic waves, and may cause vertical displacement of suspended biomass, periodic variation in light intensity, and redistribution of dissolved substances (Münnich et al., 1992).

Samplings on July $9^{\text {th }}$ showed that algal biomass at the deep peak increased around $20 \%$ between 10 a.m and 3 p.m., and increased by $50 \%$ by 8 p.m. (Fig. 6a). At 8 p.m. sampling the DCM peak had widened almost $0.5 \mathrm{~m}$ (Fig. $6 \mathrm{a})$, and the light reaching $6 \mathrm{~m}$ depth decreased. The apparent contradiction in the above mentioned increase in algal biomass at the DCM in spite the decrease in PAR light transmission could be explained by internal wave displacement of phytoplankton through a vertical light gradient (Holloway and Denman, 1989). In our study, with an amplitude of internal waves as high as $3.5 \mathrm{~m}$, the algae at the lower layers of the metalimnion were exposed to light intensities between $1 \%$ to $36 \%$ and hence, phothosyntesis could be stimulated. In our lake, Pannard et al. (2011) demonstrated that metalimnetic photosynthetic productivity fluctuated between $\pm 20 \%$ to $25 \%$. Similar results were found by Evans et al. (2011), who compared primary production incubation results from fixed versus moving depths (simulating internal waves of $0.5^{-1} \mathrm{~m}$ amplitude). Both studies found that primary production responses differed in relation to incoming irradiance, and that rates were lower still when cloud cover occurred. In our study, the lower incoming PAR irradiance on the $10^{\text {th }}$ of July $\left(170 \mathrm{~W} \mathrm{~m}^{-2}\right)$ compared to the $9^{\text {th }}\left(300 \mathrm{Wm}^{-2}\right)$ (Fig. 5a) may help explain the relative lack of algal deep peak recovery, which was 4 times lower on the $10^{\text {th }}$, relative to algal biomass on the $9^{\text {th }}$ of July (Fig. 6a). In lake Bromont, the large amplitude of internal waves in the metalimniom, driven by strong wind events, not only altered the biomass of the CYAN-DCM, but also the physical and chemical characteristics in the lower part of the meta- and hypolimnion. Nutrient enrichment in the water column has previously been linked to internal waves (Ostrovsky et al., 1996; MacIntyre and Jellison, 2001). In line with these studies, Pannard et al. (2011) showed for 2007 in lake Bromont that the vertical excursion of the metalimnion enhanced phosphorus concentrations and may have enhanced algal biomass. Increased nutrient concentrations (DP, ammonia) related to the amplitude of oscillations were also measured (data non reported). However, to our knowledge, what has not been reported in past studies is the variation in DO observed over the course of the diel sampling cycle. During this cycle, the deep metalimnion $(6.5 \mathrm{~m}$ and $5.5 \mathrm{~m})$ was initially anoxic at 10 a.m. on July $9^{\text {th }}$, but reached up to $60 \%$ saturation by midnight on July $10^{\text {th }}$. Fourfold increase in DO at $5.5 \mathrm{~m}$ depth on July $9^{\text {th }}$ from 8 pm to midnight were linked to the storm at 6 p.m. that, as mentioned before, induced larger amplitude oscillations after 9 pm (Figs. 6b, 5 b,c). The diurnal increase in amplitude of the oscillations from 9 a.m. to $5 \mathrm{p} . \mathrm{m}$. together with daytime algal photosynthesis, could explain the increase in DO from 10 a.m. to 8 p.m. On July $10^{\text {th }} \mathrm{DO}$ in morning sampling was lower $\left(<2 \mathrm{mg} \mathrm{L}^{-1}\right)$ below a depth of $6 \mathrm{~m}$, as was the recovery of the algal DCM biomass peak, possibly due to the fact that the PAR irradiance on July $10^{\text {th }}$ was almost half of that on the $9^{\text {th }}$.
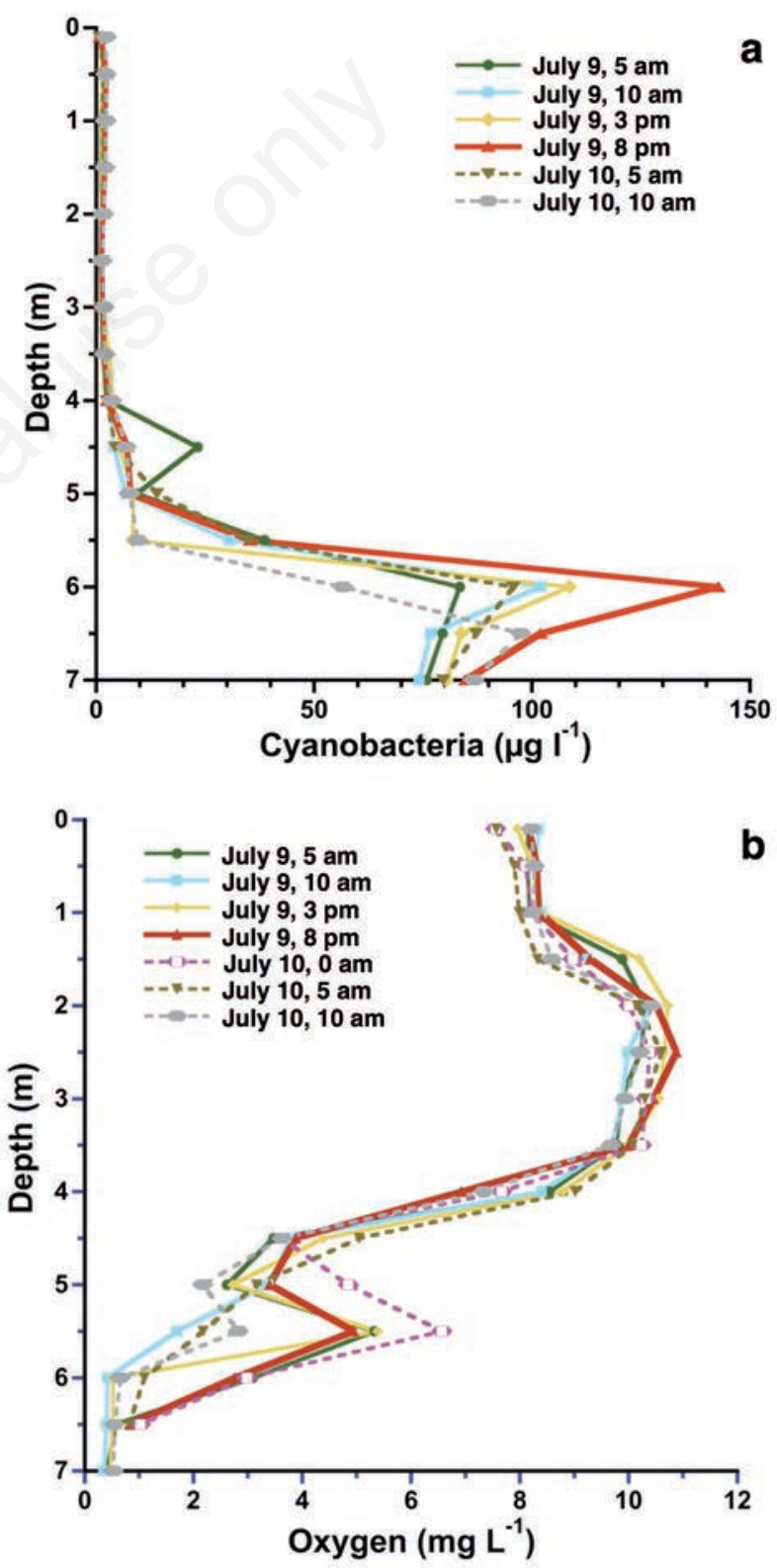

Fig. 6. Water column profiles during the cycle, including (a) cyanobacterial biomass, and (b) concentration of dissolved oxygen. 


\section{CONCLUSIONS}

In summary, in small and stratified lake Bromont, despite low external nutrient inputs during the ice-free season, cyanobacteria dominated the phytoplankton community, growing abundantly in the meta- and hypolimnion as a result of plentiful internally supplied $\mathrm{P}$, low ambient light, and low temperatures. These environmental conditions were ideal for the meta-and hypolimnetic growth and community dominance of both $P$. rubescens and $P$. agardii. The maximum biomass of cyanobacteria, up to $150 \mu \mathrm{g}$ Chla L ${ }^{-1}$, was measured between 7 to $6.5 \mathrm{~m}$, at the limit of, or below the photic zone. The $\mathrm{L}_{\mathrm{N}}$ indicated metalimnetic internal waves commonly caused the DCM algae to oscillate vertically with the waves, and to be exposed to varying light intensities, thereby enabling photosynthesis even when deep waters receive very little light. After strong wind events, the amplitude of the internal wave oscillation increased and the DCM peak was disrupted, causing blooms to appear at the surface of the lake $12 \mathrm{~h}$ after the strong wind event. Not only did the large internal wave oscillations affect nutrient and DCM algal dynamics, but they also affected DO at 6.5 to $4.5 \mathrm{~m}$ depths.

Because changes in lake Bromont local temperatures over the past 50 years are consistent with the global trend (Pachauri and Meyer, 2014), from our results, we predict that atmospheric warming and boosted wind speeds, linked to increased storm frequency and intensity, will together rise the frequency and intensity of cyanobacterial blooms. In particular, Planthotrix blooms may become more prevalent in small (surface area lower than $1 \mathrm{~km}^{2}$ ) lakes with characteristics similar to lake Bromont, which may number up to $300 * 10^{6}$, and may collectively represent $43.3 \%$ of the total global lake surface area (Downing et al. 2006).

\section{ACKNOWLEDGMENTS}

This study was made possible through funding grants to D.P. from the Fonds Québécois de la Recherche sur la Nature et les Technologies, Natural Sciences and Engineering Research Council of Canada and Horizon Science-Environment Canada. We also thank the Bromont Municipality and Action de conservation du bassin versant du lac Bromont (ACBVLB) for their monetary and in kind contributions. Data collection was made possible by the logistical help and surveillance of in situ instruments, by the ACBVLB, and by the sharing of field equipment by Beatrix Beisner. We are greatly thankful to Alexadrina Pannard for valuable discussions, as well as to Matthew Bogard. We are very thankful for field and lab assistance from all the summer assistants and grand students involved in the project, particularly Zuzana Hrivnakova, Paola Cabal Gomez, and Julien Cere.

\section{REFERENCES}

Beutler M, Wiltshire KH, Meyer B, Moldaenke C, Lüring C, Meyerhöfer M, Hensen, UP, Dau H, 2002. A fluorometric method for the differentiation of algal populations in vivo and in situ. Photosynth. Res. 72:39-53.

Buergi HR, Stadelmann P, 2000. Change of phytoplankton diversity during long-term restoration of Lake Baldegg (Switzerland). Verh. Int. Verein. Limnol. 27:574-581.

Downing JA, Prairie YT, Cole JJ, Duarte CM, Tranvik LJ, Striegl RG, McDowell WH, Kortelainen P, Caraco NF, Melack JM, Middelburg JJ, 2006. The global abundance and size distribution of lakes, ponds, and impoundments. Limnol. Oceanogr. 51:2388-2397.

Carignan R, 1984. Interstitial water sampling by dialysis: methodological notes. Limnol. Oceanogr. 29:667-670.

Carignan R, Lean DRS, 1991. Regeneration of dissolved substances in a seasonally anoxic lake: The relative importance of processes occurring in the water column and in the sediments. Limnol. Oceanogr. 36:683-707.

Catalan J, Fee EJ, 1994. Interannual variability in limnic ecosystems: origin, patterns, and predictebility, p 81-95. In: R. Margalef (ed.), Limnology now: a paradigm in planetary problems. Elsevier.

De Stasio Jr BT, Hill DK, Kleinhans JM, Nibbelink NP, Magnuson JJ, 1996. Potential effects of global climate change on small north-temperate lakes: physics, fish, and plankton. Limnol. Oceanogr. 41:1136-1 149.

Edmondson WT, Leman JT, 1981. The effect of changes in the nutrients income on the condition of Lake Washington. Limnol. Oceanogr. 26:1-12.

Evans MA, MacIntyre S, Kling GW, 2008. Internal wave effects on photosynthesis: experiments, theory, and modeling. Limnol. Oceanogr. 53:339-353.

Fee EJ, 1976. The vertical and seasonal distribution of chlorophyll in lakes of the experimental Lakes Area, northwestern Ontario: implications for primary production estimates. Limnol. Oceanogr. 21:767-783.

Feuillade J, 1994. The cyanobacterium (blue-green alga) Oscillatoria rubescens D.C. Arch. Hydrobiol. Beih. Ergebn. Limnol. 41:77-93.

Feuillade M, Druart JC, 1994. The long-term effect of the sewage diversion on the phytoplankton composition and biomass. Arch. Hydrobiol. Beih. Ergebn. Limnol. 41:55-76.

Fogg GE, Stewart WDP, Fay P, Walsby AE, 1973. The bluegreen algae. Academic Press, London: 459 pp.

George DG, Maberly SC, Hewitt DP, 2004. The influence of the North Atlantic Oscillation on the physical, chemical and biological characteristics of four lakes in the English Lake District. Freshwater Biol. 49:760-774.

Hallegraeff GM, 1993. A review of harmful algal blooms and their apparent global increase. Phycologia 32:79-99.

Halstvedt CB, Rohrlack T, Andersen T, Skulberg O, Edvardsen B, 2007. Seasonal dynamics and depth distribution of Planktothrix spp. in Lake Steinsfjorden (Norway) related to environmental factors. J. Plankton Res. 29:471-482.

Hesslein RH,1976. An in situ sampler for close interval pore water studies. Limnol. Oceanogr. 22: 913-915.

Holloway G, Denman K, 1989. Influence of internal waves on primary production. J. Plankton Res. 11: 409-413. 
Ibelings BW, Portielje R, Lammens EHRR, Noordhuis R, van den Berg RWJ, Meijer ML, 2007. Resilience of alternative stable states during the recovery of shallow lakes from eutrophication: Lake Veluwe as a case study. Ecosystems 10:4-16.

Imberger J, 1998. Flux paths in a stratified lake: A review, p. 117. In J. Imberger (ed.), Physical processes in lakes and oceans. Coast. Estuarine Stud., American Geophysical Union.

Imberger J, Patterson JC, 1990. Physical limnology. Adv. Appl. Mech. 27:303-475.

Imboden DU, Lemmin T, Joller A, Schurten M, 1983. Mixing processes in lakes: mechanisms and ecological relevance. Schweiz. Z. Hydrol. 45:1-44.

Pachauri RK, Meyer LA, 2014. Climate change 2014: synthesis report. Contribution of Working Groups I, II and III to the Fifth Assessment Report of the Intergovernmental Panel on Climate Change. Writing Team. IPCC, Geneva, Switzerland: $151 \mathrm{pp}$.

Jacquet S, Briand JF, Leboulanger C, Avois-Jacquet C, Oberhaus L, Tassin B, Vincon-Leite B, Paolini G, Druart JC, Anneville O, Humbert JF, 2005. The proliferation of the toxic cyanobacterium Planktothrix rubescens following restoration of the largest natural French lake (Lac du Bourget). Harmf. Algae 4:651-672.

Jeppesen E, Søndergaard M, Jensen JP, Havens KE, Anneville O, Carvalho L, Coveney MF, Deneke R, Dokulil MT, Foy B, Gerdeaux D, Hampton SE, Hilt S, Kangur K, Köhler J, Lammens EHHR, Lauridsen TL, Manca M, Miracle MR, Moss B, Noges P, Persson G, Phillips G, Portielje R, Romo S, Schelske CL, Straile D, Tatrai I, Willen E, Winder M, 2005. Lake responses to reduced nutrient loading - an analysis of contemporary long-term data from 35 case studies. Freshwater Biol. 50:1747-1771.

Jöhnk KD, Huisman J, Sharples J, Sommeijer B, Visser PM, Stroom JM, 2008. Summer heatwaves promote blooms of harmful cyanobacteria. Glob. Change Biol.14:495-512.

Jourdain M, 2010. [Les effets des variables environnementales sur le recrutement des cyanobactéries et des akinètes]. [Thesis in French]. Université du Québec à Montréal.

Kamarainen AM, Yuan H, Wu CH, Carpenter SR, 2009. Estimates of phosphorus entrainment in Lake Mendota: a comparison of one-dimensional and three-dimensional approaches. Limnol. Oceanogr.-Meth. 7: 553-567.

Kangro K, Laugaste R, Nõges P, Ott I, 2005. Long-term changes and special features of seasonal development of phytoplankton in a strongly stratified, hypertrophic lake. Hydrobiologia 547:91-103.

Klausmeier CA, Litchman E, 2001. Algal games: the vertical distribution of phytoplankton in poorly mixed water columns. Limnol. Oceanogr. 46:1998-2007.

Klemer AR, 1976. The vertical distribution of Oscillatoria agardhii var. isothrix. Arch. Hydrobiol. 78:343-362.

Konopka A, 1982. Buoyancy regulation and vertical migration by Oscillatoria rubescens in Crooked Lake, Indiana. Br. Phycol. J. 17:427-442.

Kosten S, Huszar VLM, Cares EB, Costa LS, Van Donk H, Hansson LA, Jeppesen E, Kruk C, Ell Lacero GSS, Mazzeo NS, De Meester L, Moss B, Rling ML, Nöges T, Romokk S, Scheffer M, 2001. Warmer climates boost cyanobacterial dominance in shallow lakes. Glob. Change Biol. 18:118-126.

LaZerte BD, 1980. The dominating higher order vertical modes of the internal seiche in a small lake. Limnol. Oceanogr. 25:846-854.

Litchman E, 1998. Population and community responses of phytoplankton to fluctuating light. Oecologia 117:247-257.

MacIntyre, S, Flynn KM, Jellison R, Romero JR, 1999. Boundary mixing and nutrient fluxes in Mono Lake, California. Limnol. Oceanogr. 44:512-529.

MacIntyre S, Jellison,V 2001. Nutrient fluxes from upwelling and enhanced turbulence at the top of the pycnocline in Mono Lake, CA. Hydrobiologia 466:13-29.

Marcé, R, Feijoo C, Navarro E, Ordoñez J, Gomà J, Armengol J. 2007. Interaction between wind-induced seiches and convective cooling governs algal distribution in a canyonshaped reservoir. Freshwater Biol. 52:1336-1352.

Menzel DW, Corwin, E, 1965. The measurement of total phosphorus in seawater based on the destruction of organically bound fractions by persulfate oxidation. Limnol. Oceanogr. 10:280-282.

Micheletti S, Schanz F, Walsby AE, 1998. The daily integral of photosynthesis by Planktothrix rubescens during summer stratification and autumnal mixing in Lake Zurich. New Phytol. 139:233-246.

Mooij WM, lsmann SH, De Senerpont Domis LN, Nolet BA, Bodelier PLE, Boers PCM, Pires L MD, Gons HJ, Ibelings BW, Noordhuis R, Portielje R, Wolfstein K, Lammens EHRR, 2005. The impact of climate change on lakes in the Netherlands: a review. Aquat. Ecol. 39:381-400.

Mortimer CH, 1974. Lake hydrodynamics. Mitt. Int. Ver. Theor. Angew. Limnol. 20:124-197.

Münnich M, Wüest A, Imboden DM. 1992. Observations of the second vertical mode of the internal seiche in an alpine lake. Limnol. Oceanogr. 37:1705-1719.

MurphyJ, Riley JP, 1962. A modified single solution for the determination of phosphate in natural waters. Anal. Chim. Acta 27:31-36.

Nõges P, Nõges T, Tuvikene L, Smal H, Ligeza S, Kornijów R, Peczula W, Bécares E, Garcia-Criado F, Alvarez-Carrera C, Fernandez-Alaez C, Ferriol C, Miracle RM, Vicente E, Romo S, Van Donk E, van de Bund W, Jensen JP, Gross EM, Hansson L-A, Gyllström M, Nykänen M, de Eyto E, Irvine K, Stephen D, Collings S, Moss B, 2003. Factors controlling hydrochemical and trophic state variables in 86 shallow lakes in Europe. Hydrobiologia 506:51-58.

Nürnberg GK, 1984. The prediction of internal phosphorus load in lakes with anoxic hypolimnia. Limnol. Oceanogr. 29:111-124.

Nusch EA, 1980. Comparison of different methods for chlorophyll and phaeopigment determination. Arch. Hydrobiol. Beih. Ergebn. Limnol. 14:14-36.

Ostrovsky I, Yacobi YZ, Walline P, Kalikhman I, 1996. Seicheinduced mixing: Its impact on lake productivity. Limnol. Oceanogr. 41:323-332.

Paerl HW, Huisman J, 2008. Blooms like it hot. Science 320: $57-58$.

Pannard A, Beisner BE, Bird DF, Braun J, Planas D, Bormans M, 2011. Recurrent internal waves in a small lake: potential ecological consequences for metalimnetic phytoplankton populations. Limnol. Oceanogr. Fluids Environ. 1:91-109.

Pannard A, Planas D, Beisner BE, 2015. Macrozooplankton and 
the persistence of the deep chlorophyll maximum in a stratified lake. Freshwater Biol. 60:1717-1733.

Parry ML, 2007. Assessment Report of the Intergovernmental Panel on Climate Change: Impacts, adaptation, and vulnerability. Cambridge University Press.

Peeters F, Livingstone DM, Goudsmit G-H, Kipfer R, Foster R, 2002. Modeling 50 years of historical temperature profiles in a large central European lake. Limnol. Oceanogr. 47:186-197.

Pomati F, Matthews B, Jokela J, Schildknecht A, Ibelings BW, 2012. Effects of re-oligotrophication and climate warming on plankton richness and community stability in a deep mesotrophic lake. Oikos 121:1317-1327.

Ramón G, Moyá G, 1984. Seasonal variations in the vertical distribution of Oscillatoria rubescens D.C. in the Gorg Blau reservoir, Spain. Verh. Int. Ver. Limnol. 22:1546-1549.

Reynolds CS, 1994. The role of fluids motions in the dynamics of phytoplankton in lakes and rivers, p. 141-187. In: P.S. Giller, A.G. Hildrew and D.G. Raffaelli (eds.), Aquatic ecology, scales, patterns and processes, Blackwell Scientific.

Robertson DM, Imberger J, 1994. Lake number, a quantitative indicator of mixing used to estimate changes in dissolved oxygen. Internat. Rev. Hydrobiol. 79:159-176.

Ruggiu D, Mosello R, 1984. Nutrient levels and phytoplankton characteristics in the deep souther alpine lakes. Verh. int. Ver. Limnol. 22:1106-1112.

Ruggiu D, Morabito G, Panzani P, Pugnetti A, 1998. Trends and relations among basic phytoplankton characteristics in the course of the long-term oligotrophication of Lake Maggiore (Italy). Hydrobiologia 370:243-257.

Salmaso N, 2000. Factors affecting the seasonality and distribution of cyanobacteria and chlorophytes: a case study from the large lakes south of the Alps, with special reference to Lake Garda. Hydrobiologia 438:43-63.

Sartory DP, Großßelaar JU, 1984. Extraction of chlorophyll a from freshwater phytoplankton for spectrophotometric analysis. Hydrobiologia 114:177-187.

Schindler DW, 1974. Whole lake eutrofication experiment with phosphorus, nitrogen and carbon. Verh. Int. Ver. Limnol. 19:3221-3231.

Solomon S, 2007. Climate Change 2007. The Physical Science
Basis. Working Group I Contribution to the Fourth Assessment Report of the IPCC. Working Group I Contributio.

Søndergaard M, Jensen JP, Jeppesen E, 2003. Role of sediment and internal loading of phosphorus in shallow lakes. Hydrobiologia 506/509:135-145.

Soranno PA, Carpenter SR, Lathrop RC, 1997. Internal phosphorus loading in Lake Mendota: response to external loads and weather. Can. J. Fish. Aquat. Sci. 54:1883-1893.

Stainton MP, Capel MJ, Armstrong, FAJ, 1974. The chemical analysis of freshwater. Bull. Fish. Res Board Can. Miscellaneous Special Publication 25: $125 \mathrm{pp}$.

Stainsby EA, Winter JG, Jarjanazi H, Paterson AM, Evans DO, Young JD, 2011. Changes in the thermal stability of Lake Simcoe from 1980 to 2008. J. Great Lakes Res. 37(Suppl.3):55-62.

Taranu ZE, Zurawell RW, Pick F, Gregory-Eaves I, 2012. Predicting cyanobacterial dynamics in the face of global change: the importance of scale and environmental context. Glob. Change Biol. 18:3477-3490.

Tooming-Klunderud A, Sogge H, Roung TB, Nederbragt AJ, Lagesen K, Glöckner G, Hayes PK, Rohrlack T, Jakobsen KS, 2013. From green to red: horizontal gene transfer of the phycoerythrin gene cluster between Planktothrix strains. Appl. Environ. Microb. 79:6803-6812.

Van Liere L, Mur LR, 1980. Ocurrence of Oscillatoria agardhii and some related species, a survey, p. 67-77. In: L. Barica and R. Mur (eds.), Hypertrophic ecosystems. Springer.

Verschuren D, Johnson TC, Kling HJ, Edgington DN, Leavith PR, Brown ET, Talbot MR, Hecky RE, 2002. History and timing of human impact on lake Victoria, East Africa. Proc. R. Soc. Lond. B. Biol. Sci. 269:289-294.

Walsby AE, Schanz F, 2002. Light-dependent growth rate determines changes in annual cycle of Planktothrix rubescens in Lake Zürich, Switzerland. New Phytol. 154:671-687.

Wedderburn EM, 1913. Temperature observation in Loch Earn with a further contribution to the hydrodynamical theory with temperature seiches. T. RSE. Earth 48:629-695.

Weyhenmeyer GA, 2001. Warmer winters are planktonic algal populations in Sweden's largest lakes affected? Ambio 30:565-571. 